\title{
Oráculo de Eros
}

Majestuosas se abren las hojas

bajo cada una de sus silentes pisadas.

Él es un inmenso instante

y sus ojos

destello, aire cálido

sabe que es la tarde y no la noche su morada

por eso extiende sus escamas antes de oscurecer

y reviste el fuego con sus manos

Es su piel

sus labios

sus brazos

la caligrafía completa

del papiro del deseo

la llave a la contemplación misteriosa

el oráculo de Eros.

1 Jenny Bernal. Bogotá, 1987. Estudiante de Licenciatura en Español e Inglés de la Universidad Pedagógica Nacional. Gestora cultural y cofundadora del Festival de Narrativa y Poesía Ojo en la Tinta. Colaboradora de la revista Contestarte de la Universidad Nacional de Colombia. Miembro del colectivo literario La Raíz Invertida. 